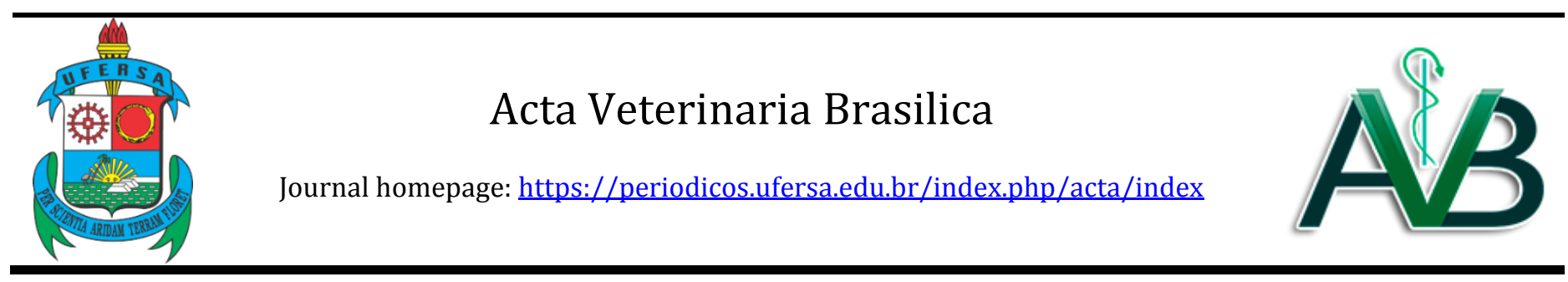

Original Article

\title{
Efficiency of chemically preserved dog's cadavers in surgical techniques training
}

\author{
Caio Sabino de Oliveira ${ }^{*}$, Angelo João Stopiglia², Julia Maria Matera² \\ 1 Veterinary Master - Department of Surgery - Faculty of Veterinary Medicine and Animal Science - University of São Paulo. \\ 2 Full Professor - Department of Surgery - Faculty of Veterinary Medicine and Animal Science - University of São Paulo.
}

\section{A R T I C L E I N F O}

Article history
Received 10 October 2016
Received in revised form 21 November
2016
Accepted 10 December 2016

Keywords:

Education

Surgery

Surgical technique

Alternative methods

\section{INTRODUCTION}

Intellectual development and motor skills are the two pillars for complete development of surgical skills. Intellectual development occurs through the study of anatomy, pathology, clinical procedures and surgical techniques, which are subjects widely taught by universities around the world, enabling students to clinically diagnose and treat animals affected by conditions necessitating surgery. Motor skills development is often neglected by educational institutions, and is primarily hindered due to the difficulty of implementing and maintaining efficient training systems, maintaining ethical and humanistic principles in the acquisition, preservation, and use of animal cadavers. In view of this, several groups of professors and researchers from all over the world are interested in the improvement of models that do not use live animals and that deliver to students a realistic simulation of a living organism, through cadavers, dolls or synthetic fabrics that mimic biological tissues, or even by simulators of surgery procedures, which has given rise different models for surgical technique teaching (SILVA; MATERA; RIBEIRO, 2004). Thus, this study aims at assessing a model of dog cadavers preserved with the modified Larssen solution, with or without prior heparinization, as well as the efficiency of the model for teaching and learning of surgical techniques.

\footnotetext{
${ }^{*}$ Corresponding author: caio.sabino.oliveira@gmail.com
} 


\section{MATERIAL AND METHODS}

Approved by the ethics committee for the use of animals of FMVZ/USP, approval number 2827/2012.

For the experiment, 14 dog cadavers were divided into 2 groups (A and B) each consisting 7 animals. Each group was subjected to the same conservation protocol, except for the use of heparin ( $5 \mathrm{~mL} / 10000$ IU per animal) in group B, immediately after euthanasia; thus, it was possible to evaluate the influence of heparinization on the quality of the viscera of dog cadavers chemically preserved with the modified Larssen solution. To facilitate management and training, we chose only canines with a maximum weight of 20 kilograms and varied sex and races. Moreover, animals that had died owing to contagious, infectious, or zoonotic diseases were not included in the study.

As described by Silva (2003), the preparation of the modified Larssen stock solution, wascarried out using $100 \mathrm{~mL}$ of $10 \%$ formalin, $400 \mathrm{~mL}$ of liquid glycerin, $200 \mathrm{~g}$ of chloral hydrate, $200 \mathrm{~g}$ of sodium sulfate, $200 \mathrm{~g}$ of sodium bicarbonate, $180 \mathrm{~g}$ of sodium chloride, and 2000 $\mathrm{mL}$ of water, between 30 and $35^{\circ} \mathrm{C}$. The ingredients were added in a container and mixed until total homogenization of the solution was achieved, and additional water was added, in order to obtain the following dilution: one part of the stock solution to three parts of distilled water.

The cadavers included in this project were from consultations that took place at non- governmental organization and from animals that died for natural reasons or were euthanized due to serious illness and with the consent of owners. In both cases, the owners authorized the use of the cadavers for teaching purposes, by signing an informed consent and donation form. In the case of euthanized animals, the owners authorized euthanasia using the euthanasia consent form. For euthanasia, intravenous thiopental at a dose of $50 \mathrm{mg} / \mathrm{kg}$ was used. After the animals were anesthetized, potassium chloride solution was infused until the hearts completely stopped functioning. In the case of animals from group B, 100,000 IU heparin was infused, immediately after death. Heparin prevents blood clotting, which enables fixation. After death, the animals were kept in the FMVZ / USP freezer (temperature between -10 and $-5^{\circ} \mathrm{C}$ ).

After thawing in water at room temperature for approximately 20 hours, the cadavers were subjected to a drying process. Subsequently, the cadavers were placed in dorsal decubitus, and the left common carotid artery and right femoral vein were cannulated. The catheter was then maintained by a simple ligature with cotton thread number 0 , and the vascular circuit was washed with water at room temperature by continuous infusion through the left common carotid artery in a volume corresponding to $10 \%$ of the weight for the animal. The right femoral vein was occluded using a surgeon's knot with a cotton yarn, and the modified Larssen solution was infused in a volume corresponding to $10 \%$ of the weight of the cadaver. The left common carotid artery was occluded usng the same procedure as for the right femoral vein. Subsequently, $20 \mathrm{~mL}$ of the modified Larssen solution was injected into the abdominal and thoracic cavity using a needle and syringe, and after the fixation, the cadavers were placed in plastic bags, identified and preserved in a cold room with temperatures between -12 and $-5 \stackrel{\circ}{\circ}$.

The cadavers were used to train a total of 14 participants, of which 12 were residents of the FMVZ / USP Veterinary Hospital and 2 were fifth year students of the undergraduate course in veterinary medicine at the FMVZ / USP. The participants, divided into pairs, took turns to operate as the surgeon and assistant to perform the techniques.

The participants received the necessary surgical supplies and instruments for performing of the techniques. The training took place once a week in a laboratory of practical classes, for a total of 10 weeks or 30 hours of surgical training.

Before each training session, an explanation was provided on the anatomy of the region to be treated and the more common conditions that would require surgical intervention. During the training session, anatomical images and illustrations of the surgical accesses from reference books in the area were projected. In order to optimize the use and preservation of the cadavers, the training was performed in the following order: digestive system (esophagectomy and enterectomy), joint system (lateral accesses to the hip and scapular humeral joints), urinary system (total nephrectomy and cystotomy), respiratory system (tracheotomy and partial pulmonary lobectomy), eye and ear (subconjunctival enucleation and lateral resection of the vertical auditory canal).

The preservation protocols were assessed using an anonymous multiple-choice questionnaire. At the end of each class, the participants provided the answers, based on their theoretical knowledge and surgical practice experience. The viscera quality was evaluated according to the organoleptic characteristics of consistency, color, handling, and odor. We considered the viscera with in natura consistency, color, and handling, and those that were odorless as those of good quality. Therefore, we used these measures to compare the two groups.

The groups were compared for each item and evaluated using Student's $t$-test. Moreover, in order to know the effect of the training on the academic and professional performance of the participants, they were asked to write testimonies with suggestions for and criticisms of the training model. 


\section{RESULTS}

The groups were compared for each item and evaluated using Student's $t$-test. For all the items, we obtained values lower than 0.05 . Thus there was no statistically significant difference between the groups. Comparison of consistency between the two groups had a p-value of 0.56791 , comparison of color had a p-value of 0.27996 , comparison of handling had a p-value of 0.519 , and comparison of odor had a p-value of 0.18273. All participants considered the training model to be of great value for the reinforcement of their surgical training. They also reported higher confidence while performing real surgeries later, although the surgeries were not the same as those practiced during the project. Most of the participants suggested the development of an established system for surgical training using cadavers for surgical residents of FMVZ / USP, as they believed that this would provide confidence to act as chief surgeons.

\section{DISCUSSION}

The results obtained showed that the training with chemically preserved dog cadavers combines the development of surgical techniques and psychomotor skills, as stated by Silva (2003), Silva; Matera; Ribeiro (2004), and Matera (2008) as they affirmed that the more realistic organoleptic characteristics of the cadaver used, as obtained through appropriate techniques of preservation and storage, the better is the training.

In the last fifteen years, many changes have occurred in practical surgery training in the veterinary field. In some faculties, students begin learning about cadavers and alternative models and complete the training in castration programs for protection of the societies, which allows training with live animals with more tranquility (GREENFIELD et al., 1991). According to some researchers, veterinary medicine students need to use live animals to know the client expectations on the use of these animals in surgery laboratories (BAUER, 1993). Veterinary schools have sought to associate the training using cadavers with training using live animals in caregiving in veterinary hospitals (BAUER, 1993; PAVLETIC et al., 1994). The same situation prevails in veterinary medicine undergraduate course in FMVZ / USP with wide acceptance from students, as observed by Silva (2003).

According to Chou; Handa (2006), besides training in animal cadavers, surgical skills develop through exercise repetition. For this reason, many institutions are adopting simulators and other training models in their residency programs, which allows exercise repetition in an individualized way, and training and development of specific skills that can be practiced to avoid exhaustion independently of cadavers conservation and use methods. Examples include the use of plastic devices, cloth, rubbers, and portable and virtual simulators. According to Aggarwal et al. (2006), Lamata et al. (2006), and Stefanidis et al. (2007), training with models or simulators could be added to the curriculum of surgery residency to familiarize doctors with advanced techniques while safely and objectively assessing their learning. According to Eerden; Nie (1981), there is no single method for the preservation of animal cadaver tissues for teaching, and researchers have sought to establish efficient and low-cost methods for the preservation of cadavers. In this project, we used the modified Larssen solution and obtained satisfactory results according to the Sampaio (1989), Silva (2003), Silva; Matera; Ribeiro (2004), Matera (2008), and Souza (2012) methodology.

During the preparation, the common carotid artery was used for lavage and preservation fluid diffusion, as described by Silva (2003), Silva; Matera; Ribeiro (2004), Souza (2012), Hoshino; Bradbury (1978), and Rodrigues (1998). Although these authors report that the lavage fluid should be drained through the direct femoral vein (or in some the right jugular vein), in this study, this drainage was observed in a single animal. During infusion of the conservative solution, solution drainage was observed through the nostrils, mouth, and anus of six animals ( 3 from Group A and 3 from Group B).

Although Sampaio (1989) reported that the Larssen solution, besides preserving organoleptic characteristics of the tissues, also dissolves clots and restores blood volume, this phenomenon was not observed in the present study, and no difference in perfusion was observed between the animals of both the groups. Using heparin immediately after euthanasia, which aims at preventing the formation of clots, and thus providing better perfusion the conservative solution, in turn, did not result in a difference in perfusion between the two groups as reported by Silva (2003).

There was no statistical difference in color, consistency, handling, and odor between the two groups, this may be due to the temperature increase caused by refrigeration problems in the cold chamber. It is important to note that several authors consider the storage of cadavers at low temperatures as the only efficient method for preservation (HOLMBERG; COCKSHUT; BASHER, 2003; JUKES; CHIUIA, 2003; PAVLETIC et al., 1994).

Although no statistically significant difference was found, Group B presented a greater number of votes for "odorless" quality than Group A, which could result in a greater comfort to the participants and greater acceptability to training, since foul odor is a limiting factor for learning. Although Silva; Matera; Ribeiro (2004) and Souza (2012) report that external cleaning of cadavers is effective in reducing unpleasant odors, this study did not use this methodology and still obtained satisfactory results. Furthermore, the skin quality in the 
inguinal and abdominal regions was friable and with hair detachment, as described by Silva (2003), which may occurr due to the smaller amount of hair in these regions, skin fragility, detachment during the thawing process or deprivation of freezing in some regions during the cold chamber storage process. These possibilities highlight the need for suitable conditions of organization and storage.

Although some recent studies present different techniques and preservation solutions (JAUNG; COOK; BLYTH, 2011; SILVA; MATERA; RIBEIRO, 2004), preservation of viscera cavity is still a laborious process, which requires time and dedication. The primary difficulty is to preserve contaminated structures, such as the hollow viscera, with minimal changes in tissue consistency to provide an adequate and close to reality surgical training. All the participants considered the surgical training model of paramount importance and suggested its implementation in the Veterinary Surgery Residency Program of FMVZ / USP, as they would be more confident and be able to practice surgical interventions on live animals, as reported by Bauer (1993), Pavletic et al. (1994), Molinas et al. (2004), Najmaldin (2007), Matera (2008) and in accordance with the findings of Silva (2003) and Souza (2012) on the importance of efficient training in cadavers before real surgical interventions.

\section{CONCLUSIONS}

The use of the modified Larssen solution preserved dog cadavers for a longer time, independent of heparinization during preparation, while maintaining the organoleptic characteristics of the tissues.

The use of chemically preserved dog cadavers is an efficient model for surgical technique training.

\section{ACKNOWLEDGEMENT}

We thank the funding agency of this project, CAPES Coordination for the Improvement of Higher Education Personnel.

\section{REFERENCES}

AGGARWAL, R.; GRANTCHAROV, T.; MOORTHY, K.; HANCE, J.; DARZI A. A competency-based virtual reality training curriculum for the acquisition of laparoscopic psychomotor skill. The American Journal of Surgery, v.191, p. 128-33, 2006.

BAUER, M. S. A survey of the use of live animals, cadavers, inanimate models, and computers in teaching veterinary surgery. Journal of American Veterinary Medical Association, v. 203, n. 7, p. 1047-1051, 1993.

CHOU, B.; HANDA, V. L. Simulators and virtual rality in surgical education. Obstetrics and Gynecology Clinics of North America, v. 33, p. 283-96, 2006.
EERDEN, W. J. van der; NIE C.J. van. Report of an international questionnaire concerning the embalming and storage of human bodies. Acta Anatomica, v. 111, p. 37, 1981. Presented in the $6^{\text {th }}$ European Anatomical Congress.

GREENFIELD, C.L.; JOHNSON, A.L.; ARENDS, M.W.; WROBLEWSKI, A.J. Development of parenchimal abdominal organ models for use in teaching veterinary soft tissue surgery. Veterinary Surgery, v. 22, n. 5, p 357-62, 1991.

HOLMBERG, D. L. ; COCKSHUT, J.R.; BASHER, A.W.P. Use a dog abdominal surrogate for teaching surgery. Journal of Veterinary Medical Education, v. 20, n. 3, p. 107-11. 1993.

HOSHINO, K.; BRADBURY, S. A. An improved imbalming procedure for long- lasting preservation of the cadaver for anatomical study. Acta Anatomica, v. 101, p. 97103, 1978.

JAUNG, R.; COOK, P.; BLYTH, P. A comparation of embalming fluids for use in surgical workshops. Clinical Anatomy, v. 24, n. 2, p. 155-161, 2011.

JUKES, N.; CHIUIA, M. From guinea pig to computer mouse: alternatives methods for a profressive, humane education. 2 ed. England: International Network for Humane Education (InterNICHE), p. 520.2003.

LAMATA, P. S.; GÓMEZ, S.J.; SÁNCHEZ-MARGALLO, F.M.; LÓPEZ, O.; MONSERRAT, C.; GARCÍA, V., ALBEROLA, C.; FLORIDO, M.A.; RUIZ, J.; USÓN, J. Laparoscopic virtual reality simulador: didatic design and technical development. Computers Methods and Programs in Biomedicine, v. 85, p. 273-283, 2006.

MATERA, J. M. O ensino de cirurgia: da teoria à prática. In: CONGRESSO BRASILEIRO DE BIOÉTICA E BEM-ESTAR ANIMAL, 1.; SEMINÁRIO NACIONAL DE BIOSSEGURANÇA E BIOTECNOLOGIA ANIMAL, 2008, Recife. Anais... 2008. p. 96-99.

MOLINAS, C. R.; BINDA, M.M.; MAILOVA, K.; KONINCKX, P.R. The rabbit nephrectomy model for training in laparoscopic surgery. Human Reproduction, v. 19, n.1, p. 185-190, 2004.

NAJMALDIN, A. Skill training in pediatric minimal access surgery. Journal of Pediatric Surgery, v. 42, p. 284-289, 2007.

PAVLETIC, M. M.; SCHWARTZ, A.; BERG, J.; KNAPP, D. An assessment of the outcome of alternative medical and surgical laboratory program at Tufts University. Journal of American Veterinary Medical Association, v. 205, n. 1, p. 97-100, 1994.

RODRIGUES, H. Técnicas anatômicas. 2. ed. Vitória, ES: [s.n.], 1998. p.222.

SAMPAIO, F. J. B. Estudo do crescimento do rim humano durante o período fetal. 1989. p. 102. Tese (Doutorado em Morfologia) - Escola Paulista de Medicina, São Paulo, 1989.

SILVA, R. M. G. da. Avaliação do método de ensino de técnica cirúrgica utilizando cadavers quimicamente preservados. 2003. Tese. 127 f. (Mestrado em Clínica Cirúrgica Veterinária) - Faculdade de Medicina Veterinária e Zootecnia da Universidade de São Paulo, São Paulo, 2003.

SILVA, R. M. G.; MATERA, J. M.; RIBEIRO, A. A. C. M. Preservation of cadavers for surgical techinique training. Veterinary Surgery, v. 33, p. 606-609, 2004

SOUZA, M. C. C. M. I. de. Desenvolvimento e avaliação de método substitutivo para a prática da hemostasia em cadáveres quimicamente preservados. 2012. 81 f. Dissertação (Mestrado em Clínica Cirúrgica Veterinária) - Faculdade de Medicina Veterinária e Zootecnia, Universidade de São Paulo, São Paulo, 2012. 
STEFANIDIS, D.; SCERBO, M.W.; KORNDORFFER, J.R. Jr.; SCOTT, D.J.

Redefining Simulator proficiency using automaticity theory. The

American Journal of Surgery, v. 193, p. 502-506, 2007. 